Article

\title{
Sustainable Agriculture and Innovation Adoption in a Tropical Small-Scale Food Production System: The Case of Yam Minisetts in Jamaica
}

\author{
Clinton L. Beckford \\ Faculty of Education, University of Windsor, 401 Sunset Avenue, Windsor, Ontario, N9B 3P4, \\ Canada; E-Mail: Clinton@uwindsor.ca
}

Received: 20 January 2009 / Accepted: 19 March 2009 / Published: 30 March 2009

\begin{abstract}
Grown in Jamaica since the days of slavery, food yams are major staples in local diets and a significant non-traditional export crop. The cultivation system used today is the same as 300 years ago, with alleged unsustainable practices. A new cultivation system called minisett was introduced in 1985 but the adoption rate twenty four years later is extremely low. This paper analyzes the prospects for the widespread adoption of minisett and sustainable yam cultivation and advocates that greater use be made of farmers' extensive knowledge of the complex agro-ecological, socio-cultural and economic milieu in which they operate.
\end{abstract}

Keywords: Minisett; innovation diffusion; innovation adoption; sustainable agriculture; yams; yam sticks; local knowledge.

\section{Introduction}

Members of the genus Diascorea, food yams, have been grown in Jamaica for over 300 years. Today yam cultivation is an important component of the local economy employing surplus labor, earning foreign exchange and serving a significant import substitution function. The dominant production system today is the same as 300 years ago, and some observers have pointed to certain economic and environmental inefficiencies which are identified later in this paper. Farmers have not embraced alternative production modes and this paper highlights how the divergence between farmers' local knowledge and Western science impact the decision-making process of farmers with regard to agricultural innovation adoption and adaptation more generally.

The yams referred to in this article are food yams, which are members of the genus Diascorea. These are distinct from the tubers North Americans commonly call yams, which are known as sweet 
potatoes throughout the Tropics. Figure 1 demonstrates the distinction between yams and sweet potatoes.

Figure 1. Sweet Potatoes on the left and Yams on the right.

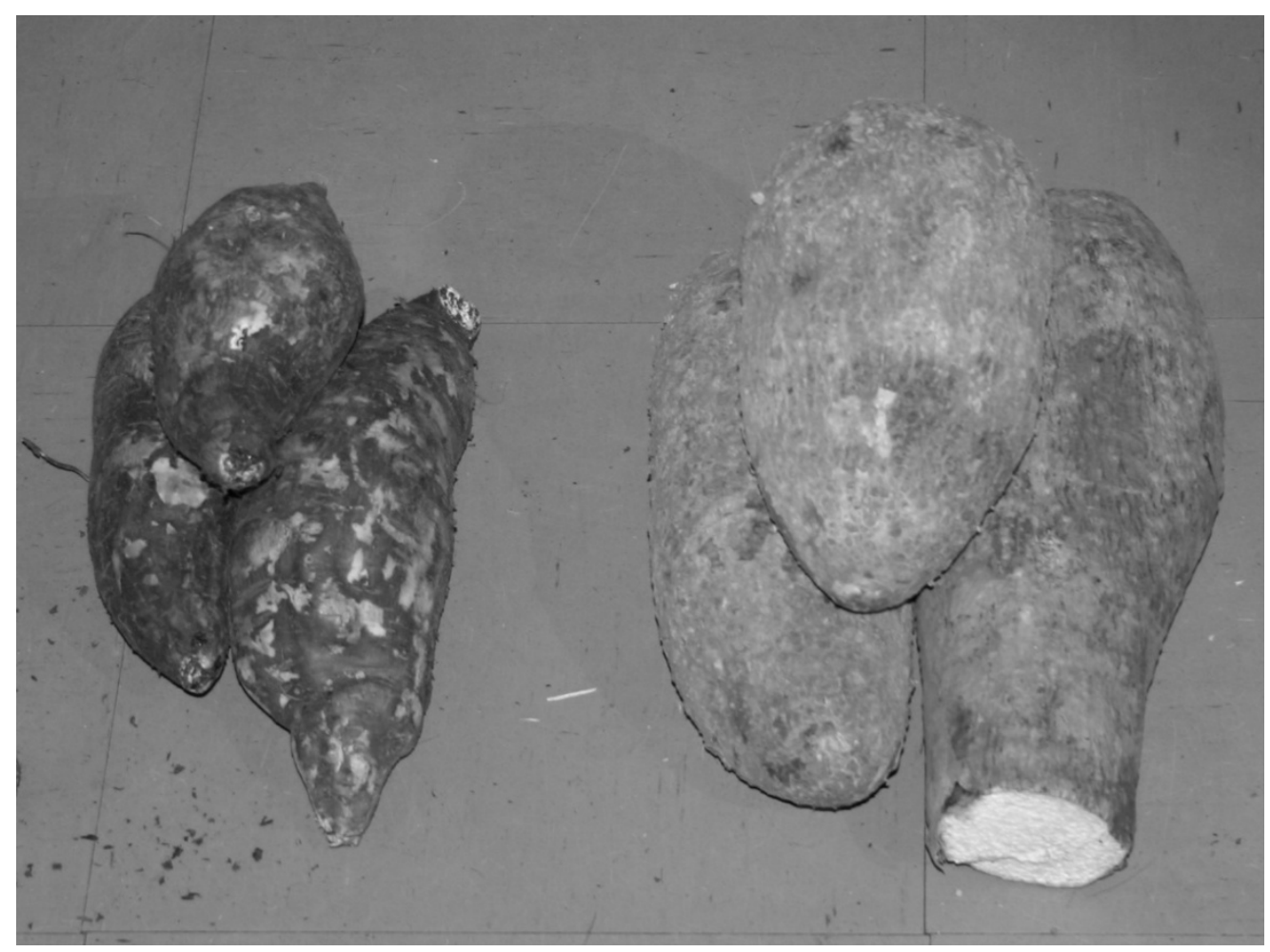

The traditional yam cultivation system in Jamaica involves large head setts [0.5-2.0 kgs] planted in individual hills or mounds at densities of up to 3,000 hills per hectare [1,2]. At an average of three kilograms of planting material per hill, seed rates [planting material] can be as high as nine tons per hectare to produce yields of 10 tons per hectare [2]. The system also requires the use of vertical stakes called yam sticks to support yam vines [See Figure 2] and it is estimated that between 43 and 60 million stakes are used annually [2,3]. The yam vines climb the poles creating an aerial biomass (see Figure 3), which according to farmers' wisdom, is critical to good yields. Traditionally yam sticks were obtained by farmers who cut saplings from local forests and woodlands. Three hundred years of exploitation and the rapid expansion and intensification of yam cultivation in the last 30 years have led to the depletion of local sources of yam sticks and the development of an informal commercial trade in the commodity [4,5]. Scarcity of yam sticks, their short lifespan and high price have given rise to an integrated problem which puts viable yam cultivation at risk [4-7]. A study by the FAO in the early 1990s concluded that price of yam sticks would increase to the point where it was uneconomical to farm yams [7]. This prognosis is alarming given the important role that this crop plays as significant economic activity to thousands of rural households, its importance as a staple food and its growing foreign exchange earnings [8]. 
Figure 2. A pile of yam sticks before transported to the field. The sticks are delivered by trucks and then moved to the fields on donkeys.

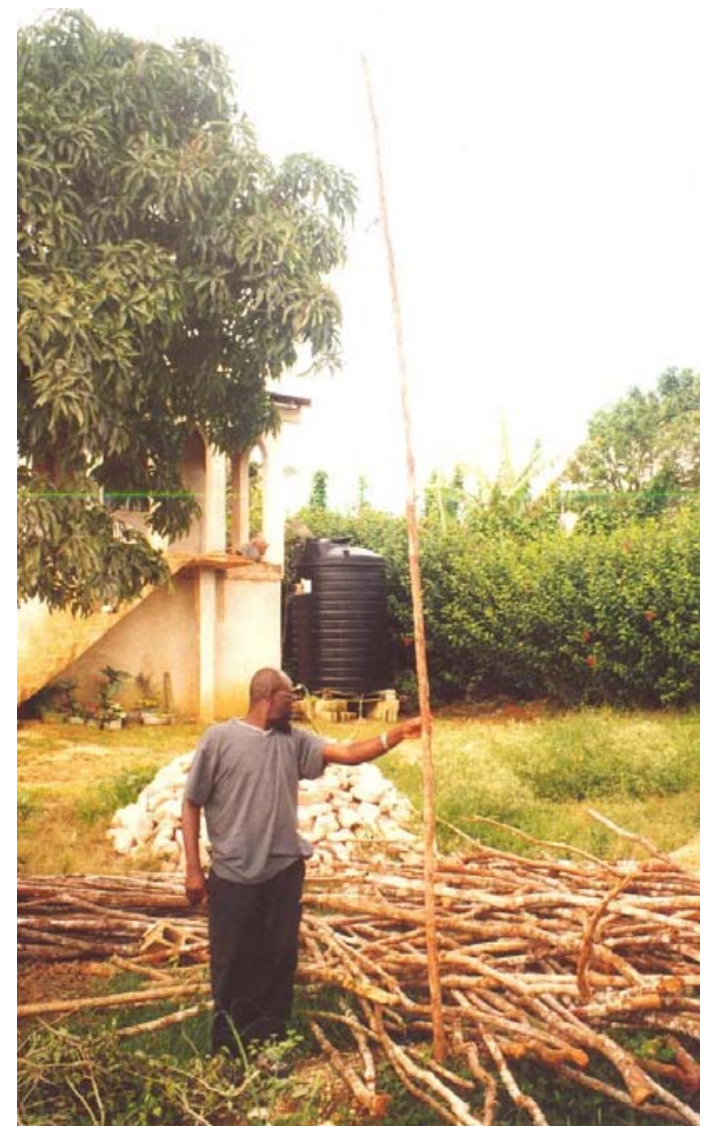

The minisett system of yam production is based on the rationale that all parts of the yam tuber can sprout and produce yams. In the traditional system only head setts are used as planting material. Minisett in contrast uses small head, middle and tail setts.

Figure 3. Yams growing in the field. The vines climb the yam sticks and create an aerial biomass which impacts productivity.

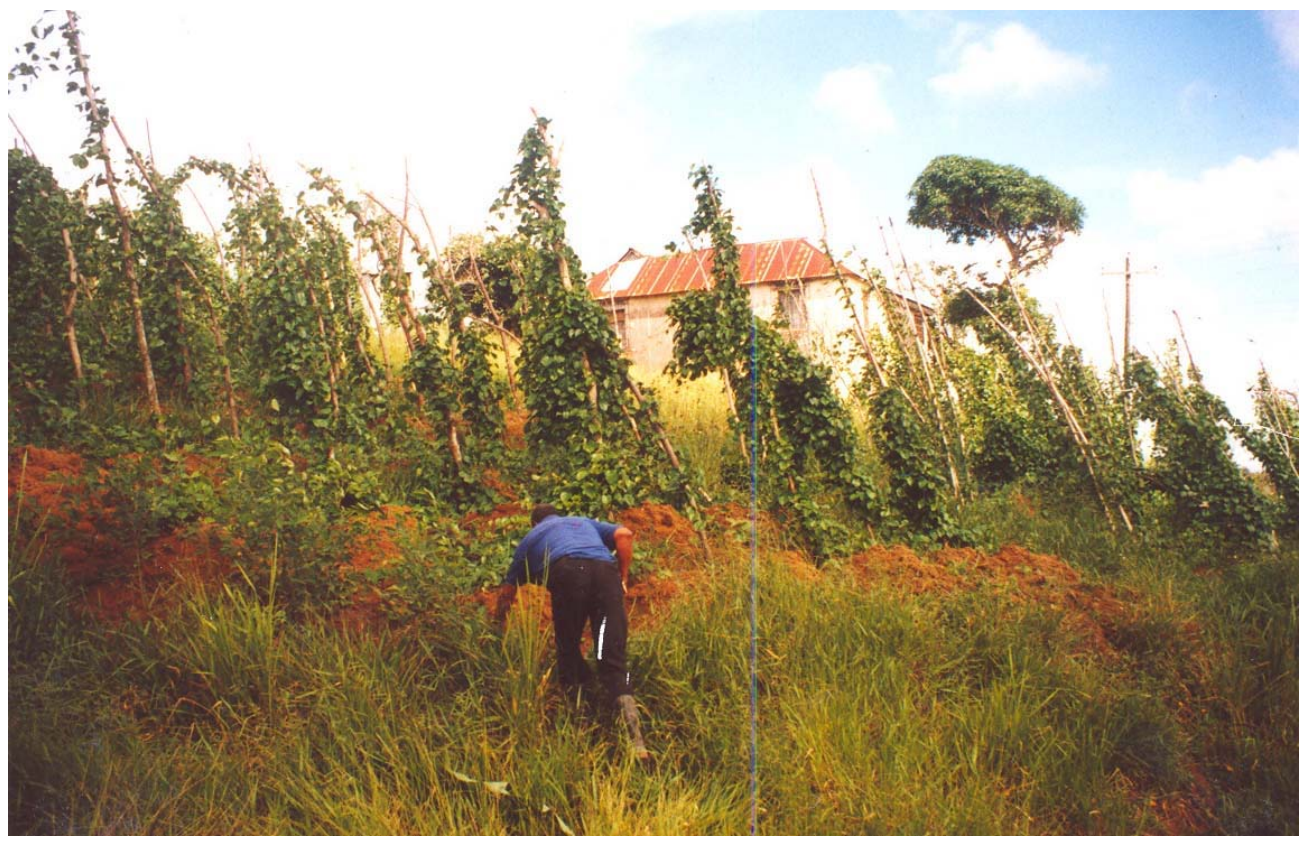


A minisett is defined as a sett, which is one quarter the size of the normal planting piece [9,10], (see Figure 4). It involves the cutting of mother tubers into small setts, each with a piece of skin intact [2]. The technology was developed by farmers in Nigeria and later refined by the International Institute for Tropical Agriculture [IITA] and is used in Nigeria and other African countries to produce small whole seed yams, which are then used as planting material [11].

Figure 4. Yam minisetts being prepared for planting at an experimental station. Planting material for yam minisetts (photograph by the Inter-American Institute for Co-operation in Agriculture, 1996).

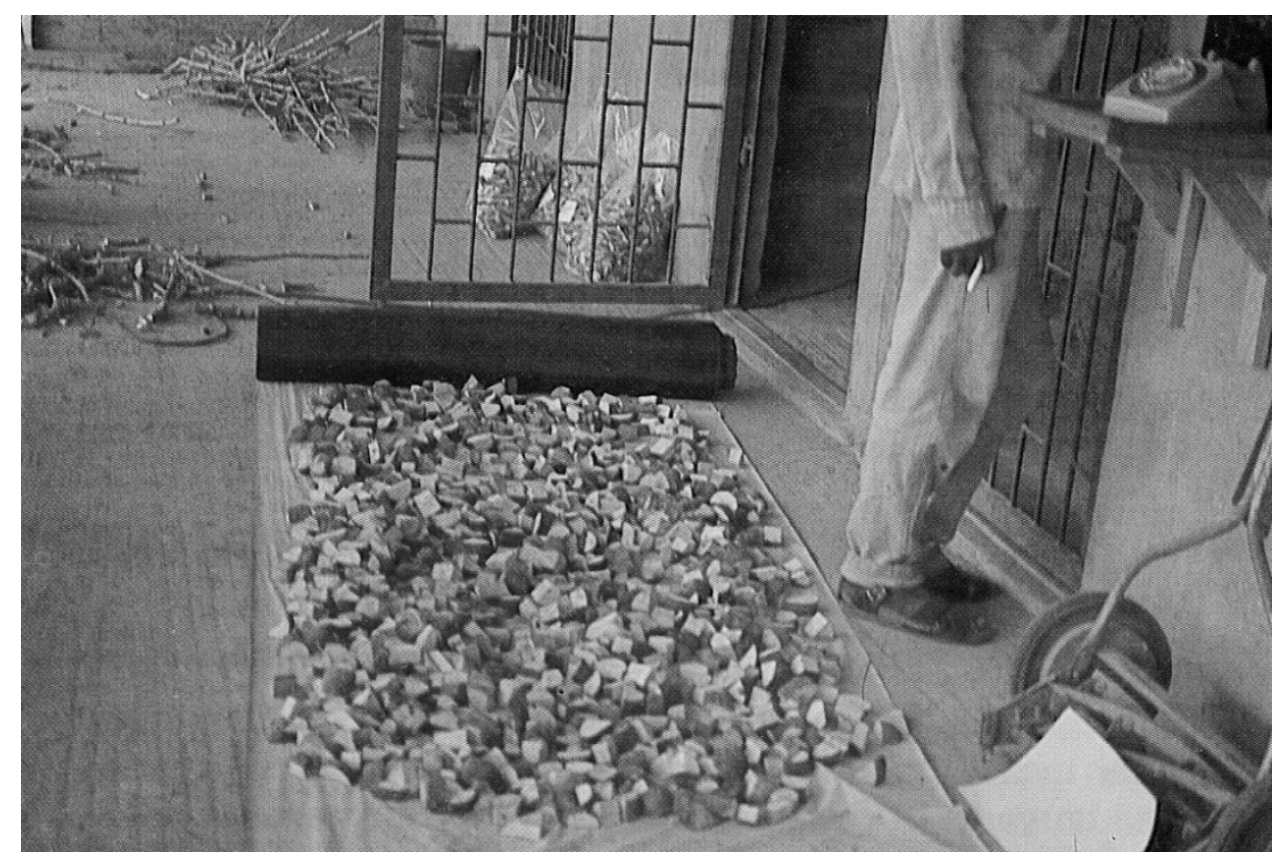

The system was introduced into Jamaica in 1985 to address some of the problems associated with the traditional yam cultivation system. Principal among these was the use of large setts for planting material, which required the use of large hills and stakes, thus contributing to increasingly high production costs. Second, the production of irregularly shaped yam tubers, which some argue are unattractive to purchasers thus limiting market expansion [12]. Third, the necessity to cut the tubers to facilitate packing for export increases the number of open surfaces, which requires the use of postharvest chemical treatment prior to export [12].

The traditional method is also alleged to have adverse environmental impacts. First of all channels tend to form between individual hills and these serve to concentrate water runoff and aggravate soil erosion on hillsides during heavy rainfall [13]. This problem is considered to be significant since yam is considered a hillside crop and most yam farms consist of plots on slopes as steep as 30 degrees. Secondly, the removal of trees from hillsides and mangroves to use as yam sticks ultimately leads to the degradation of watersheds $[4,12,6]$. The technological transfer and dissemination of minisett technology was designed to promote a system, which was less laborious, more productive and profitable and more environmentally sustainable than the traditional production system $[12,14,15]$. To date very little success has been achieved in the adoption rate of any of the minisett components [3]. 


\section{Methodology}

This paper is based primarily on data collected from 316 farmers in the yam growing belt in southern Trelawny (see Figure 5). The sample was selected by a census approach in which all the farmers operating a carefully delimited area were targeted. This area was part of the Project Land Lease program implemented by the Government of Jamaica in the 1970s to provide small-scale farmers with land to farm. The parish of Trelawny produces nearly 40 percent of the national yam production and was the highest or second highest producer of domestic food crops between 1990 and 2007. The communities studied are located in the highest yam producing extension districts in the region and the country as a whole. The paper is a culmination of over a decade of research conducted between 1995 and 2007. The research employed a variety of complimentary fieldwork strategies that utilized quantitative and qualitative research techniques. There was also a very large element of participatory and collaborative research approaches with the research participants being actively involved in the process of creating and clarifying knowledge. Data were collected using questionnaires, interviews, ground-truthing exercises and participant observation. The principal data collection procedure was a survey administered to the 316 farmers. Participant observation was extensively used with the researcher spending time living in the community and participating in farm activities. Ground truthing techniques included small-scale field experiments and triangulation of data through counting and measuring phenomena on randomly selected yam plots. Other key components of the methodology include visual aided dialogue and manual discriminant analysis. Visual aided dialogue involves discussing items that are in front of the respondents or activities in progress at the time of the interview [16].

Figure 5. General location map of the study area.
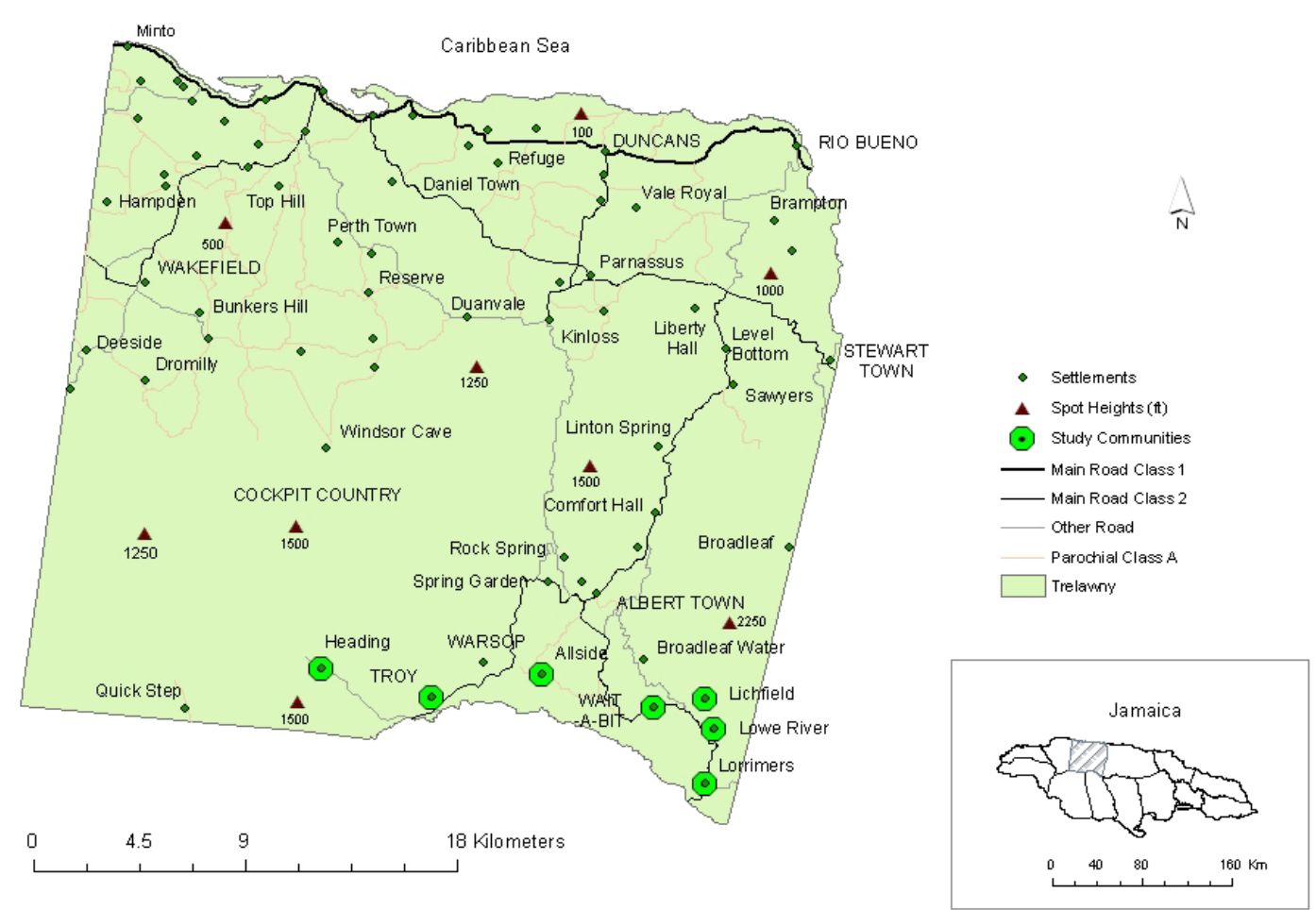
In this study, for example, farm practices being engaged in during visits to farms were discussed. Manual discriminant analysis was used in discussions with farmers about the practices of other farmers in their community, which differed from their own. Farmers were asked to explain the agricultural behavior of others in comparison to their own. The strategy is used for comparing and contrasting and provides a framework, which helps farmers to recognize their own distinctiveness [16].

\section{Findings}

\subsection{Cultural Ecology and Agro-ecology of Small-scale Food Farming in the Study Area and Jamaica}

\subsubsection{Demographic characteristics}

Eighty nine percent of the farmers were males, with 11 percent being females. The average age of the farmers surveyed was 46 yrs and 2 months, which is below the average age of farmers for the country as a whole. Most of the participating farmers were only modestly educated, with eighty-two percent of the farmers having completed only elementary school education. Eighty-one percent of the farmers classified themselves as full time, while 19 percent were part-time. The importance of farming in these communities is underlined by the fact that 196 farmers (90.74 percent) identified farming as their main economic activity.

\subsubsection{Synopsis of farming practices in the study areas}

Farmers in this study were typical of small-scale domestic food crop producers in Jamaica. The vast majority of them cultivate marginal lands on gently to steeply sloping terrain. Soils in the area tend to have high clay content, and are generally suitable for yam cultivation. Just over nine percent of farmers in the study farmed lands within the boundaries of the Cockpit Country rain forest to take advantage of the free draining bauxite soils considered to the most ideal for yam cultivation. Yam cultivation in the area occurs under totally rain-fed conditions. Rainfall is unpredictable and drought is a serious, costly and ubiquitous phenomenon. The Ministry of Agriculture in Jamaica identifies several ravaging droughts as major factor in the 40 percent decline of domestic food crop production between 1996 and 2004.

The average size of farms was two hectares and farmers on average had two thirds of their farm under cultivation at any given time. Uncultivated land was usually in fallow or was not cultivated due to lack of resources. Around 94 percent of the land under cultivation was planted with yams and over 95 percent of yam plots were mono-cropped. This high incidence of mono-cropping is not typical of small-scale farming in Jamaica or the wider Caribbean, where mixed and multiple cropping are ubiquitous features of small-scale farming [17-20].

There was a high incidence of farm fragmentation in the study area, as farmers operated land in many different locations in response to their inability to access adequate land in contiguous parcels. The calculated farm fragmentation index was 3.8. For some farmers fragmentation was a deliberate agronomic practice designed to spread their risks and utilize different advantageous ecological niches represented by different soil characteristics and micro-climates [21]. 
Closely related to farm fragmentation is the issue of land tenure. A variety of land tenure arrangements were observed ranging from conventional legal protocols of ownership, leasing and renting to a range of customary and informal arrangements including family land and illegal arrangements like squatting. Only 32 percent of the land operated by farmers in the study was owned. This underscores the problem of insecure tenure, which is a major obstacle facing small-scale food crop cultivators in Jamaica.

Over 90 percent of the farmers in the study employed wage labor, but only 42 percent did so on a regular basis. While hard to quantify, a significant amount of farm labor was procured through customary labor arrangements, which typically do not involve the paying of wage. The two most widely used strategies are partnership and day for day. The former is an informal cooperative of several farmers who spend designated days rotating among each others' farms. In the latter work days are exchanged on a reciprocal basis. Both are adaptive money-saving devices grounded in tradition and critical components of the socio-cultural aspects of farming and rural life.

\subsubsection{Political and economic constraints}

Agriculture in Jamaica is characterized by an entrenched dual structure [22]. There is a large scale, export oriented sector and a small-scale domestic oriented sector. The export agricultural sector is related to the traditional export crops especially sugar, coffee and banana. These are grown on medium to large size farms and in the case of sugar and bananas on large plantations. Historically these crops have enjoyed a position of privilege in respect to status and prestige. They occupy the best lands in the fertile coastal alluvial valleys and interior plains while small-scale domestic food farms typically exist on marginal lands in the hilly interior. This is a historical phenomenon dating back to the days of slavery and the period immediately following full emancipation in 1838 [21].

The export sector benefits from access to irrigation and other modern agricultural inputs. It gets a disproportionate slice of agricultural funding and benefits disproportionately from agricultural research and development projects and loans [21,22]. The small-scale sector on the other hand experiences certain biases in these areas. This sector accounts for the greater proportion of farm labor and produces a wide range of crops, mainly for the domestic market. The small-scale sector emerged significantly after 1838, when the slave population was freed and the ex-slaves withdrew from the estates, established rural communities called free villages and set up the independent peasantry, which became the backbone of the Jamaican agricultural sector. The structural dichotomy in Jamaican agriculture is, therefore, a persistent feature of local agriculture with historical roots in the period of colonial expansion in the eighteenth and nineteenth centuries when the economy was based on plantation agriculture and slave labor [22]. Small-scale domestic crop producers are rarely able to access development loans for their farms, as they do not possess the collateral requirements of the traditional lending institutions. Very little research is conducted on the crops grown by these producers and very little agricultural extension is available to them. These farmers are resource poor and engage in agriculture that is diverse, complex and high risk. They are, however, rich in traditional knowledge, resilience and survival instincts. Despite the challenges and obstacles they face the small-scale farming sector remains an integral part of the development of Jamaica the importance of, which typifies the activities of the majority of rural families [21]. 
The significance of agriculture among rural families goes beyond satisfying household needs to playing a crucial role in the national drive towards food security through increased domestic food production. This being said, it should be pointed out that small farmers do not simply produce food for the domestic market. Since the nineteenth century these farmers have been successfully cultivating export crops like sugar and bananas. In addition many of the designated domestic crops now earn valuable foreign exchange for the country under the category of non-traditional exports. For example, yam exports averaged over US\$12 million annually between 1995 and 2004 [23]. Exports of nontraditional exports were valued at US\$94,964.00 in 2001 [24]. These accomplishments are achieved in spite of the persistent spatial dualism and the disadvantaged position of the small-scale farming sector in regards to the country's resource base (see [21]). It is against this background that any analysis of small-scale farming has to be conducted. The treatment of the small-scale farming sector by agricultural agencies of government does not instill confidence in domestic food crop producers of their ability to solve farmers' problems. Therefore, all other things being equal most farmers will back their own knowledge and experiences unless something clearly superior is offered by outsiders. In any event as numerous examples from the tropics indicate, poor communities hold the key to the solution to their own problems.

\subsection{The Advantages of Minisett}

The minisett yam cultivation system is said to have several distinct advantages over the traditional system. It has been argued that minisetts produce better yields by utilizing high density planting to maximize land use and increase production per unit area of cultivated land [2]. Purportedly, the small tubers produced not only produce more tuber per unit of planting material than larger setts but, can also be planted at greater densities to maximize yield per unit area of land.

Minisett is said to use improved quality of planting material, which increases the potential for producing high yields. The treatment of setts with chemicals reduces the susceptibility of some types of yams to nematode build-up. Third, the use of minisetts increases the availability of planting material. In the traditional system yam production depends on the availability of 'head' setts for planting. The minisett system employs the use of fungicides to make middle and tail setts productive [2].

The shape and the size of the tubers produced are also identified as advantages. Minisett yams tend to be uniformly straight, thus facilitating easy grading and packaging. Additionally, the size and shape are considered to be attractive for the export market. This point is contested by farmers in the study area, who argued that big yams are more desired by exporters. Also, for reasons that are not quite clear tuber hallowing seems to occur much less frequently in small tubers than large ones [2]. A fifth advantage claimed is reduced labor requirements. The technology uses methods, which control weeds, prepare land mechanically and eliminate the use of stakes, thereby circumventing much of the main labor costs incurred in the traditional system like weeding, staking and manual land preparation [2].

Minisett technology is also considered to be more environmentally sustainable as it incorporates the use of continuous mounds and grass or plastic mulch to reduce soil loss. In the traditional system individual hills are used and these are kept free of weeds often leading to considerable soil loss during 
heavy rainfall [2]. This is important as yams are often planted on free draining soils on slopes that are generally very susceptible to erosion.

It is also argued that minisett facilitates the production of yam all year round. Pre-sprouting of middle, head and tail setts allows for variations in planting dates, which also means variations in harvesting times [2]. Income is, therefore, spread throughout the year. In addition, minisett is promoted as a valuable export crop, which does not require the use of post harvest chemical treatment prior to export. In the traditional yam stick method the number of cut surfaces on yams prepared for export make it necessary for chemical treatment to avoid contamination and spoilage. This increases the risk of purchasing countries rejecting Jamaican yams if traces of chemical residues are found. Minisett is also touted as a technology which can be applied on hillsides in a sustainable way and is claimed to be a low risk crop with a secure export market, which will yield good profits [25].

\subsection{Farmers' Perception of and Attitudes towards Minisett Yams}

Recent studies in the main yam growing area of Jamaica have provided useful insights into the attitudes of farmers towards minisett yam cultivation and the prospects for its wide spread adoption by small-scale yam producers in the country [4,26-27]. One of the major findings is that the attitude of farmers is influenced by many factors (Table 1). The table summarizes answers given by respondents which were interpreted and coded into specific factors that influenced the decision-making of farmers. These were then categorized under a number of broad emergent themes with economic and environmental factors being most prevalent. These studies also indicated that most farmers in the study areas were only vaguely aware of the technology. Most knew of its existence, but the vast majority had very little knowledge of its operation.

Table 1. The main factors influencing the attitude of farmers to minisett.

\begin{tabular}{ll}
\hline Factors & Category \\
\hline Economic security & Economic \\
Low market demand & Economic \\
Small tuber/yield & Economic \\
High risk & Economic \\
Cultural ecology & Socio-cultural \\
Family tradition & Socio-cultural \\
High production costs & Economic \\
Lack of information & Institutional \\
Lack of understanding & Personal/Institutional \\
Dissemination strategy & Institutional \\
Soil/drainage constraints & Environmental \\
Slope & Environmental \\
Terrain constraints & Environmental \\
Personal preference & Personal \\
Resistance to change & Personal/psychological \\
\hline
\end{tabular}


Many of the farmers did not know of the system by its correct name. Initially when farmers were asked if they knew about minisett most answered no. When the system was described, however, most of the respondents said that they had at least heard of it. The farmers referred to minisett yam as 'plastic yam' because of the use of plastic mulch to cover yam mounds.

Over 90 percent of the farmers had never even visited a minisett plot close up and less than two percent had ever used any of the components of the minisett package. The attitude of farmers in the study areas to minisett was clearly linked to their perception of the system. The farmers' attitude was encapsulated in the statement that "minisett cannot help us." This means that in their minds minisett has no economic benefits. The negative attitude to minisetts was also reported by field officers of the Rural Agricultural Development Authority (RADA), who reported an intense resistance among farmers in the area to the system.

The farmers in the study were able to articulate a number of reasons for their negative views about minisett. One of the fundamental concerns was the smaller tubers it produced, which advocates actually claim is an advantage. Closely related to tuber size is the issue of yield. Seventy nine percent of the farmers felt that because minisett produced a much smaller tuber than the traditional system, yields were, therefore, smaller, which of course is not necessarily true. The bigger tubers produced using the traditional system, were more desired by the farmers, who were yet to be convinced that minisett yams are more marketable than the traditional yams. In fact it was suggested that the smaller tubers were more difficult to market as exporters were unwilling to take yams, which were too small. This claim of was substantiated by officials at an agricultural export plant which purchased yams from the farmers.

Figure 6. Yams packed for export. The farmers' contention that big yams are favored by exporters was confirmed on our visit. This $30 \mathrm{~kg}$ box had five pieces of yam.

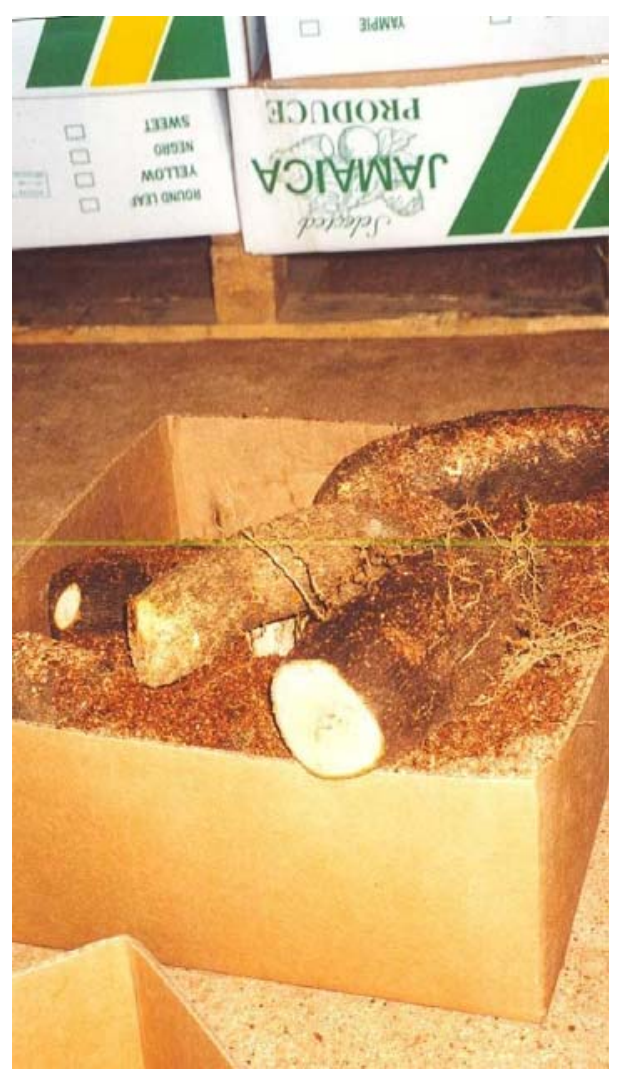


An examination of boxes packed for export revealed that most of the yams weighed in excess of 6 kilograms (Figure 6). Each box was packed with $30 \mathrm{~kg}$ and had four to five pieces of yams on average. Officials at the plant explained they many West Indians and Africans in the United Kingdom, Canada and the United States liked big yams. It was felt that especially in the UK, where many West Indians migrated in the 1950s and 60s, large yams were still generally preferred. Research in progress in Ontario (Canada) suggests that younger people may in fact prefer smaller yams, while older people preferred bigger yams.

Twenty seven percent of the farmers argued that minisett yam cultivation has soil and terrain constraints. It was argued that the heavy clay soils in the area were not conducive to the use of plastic mulch. Given their high water retention capacity, clay soils once thoroughly wetted and covered with the plastic mulch could become waterlogged and cause rotting. This is an excellent example of local knowledge at work. The role of local knowledge in survival strategies of small-scale Caribbean farmers is the subject of recent research based on Jamaican data $[8,21,28]$.

An interesting argument raised by a group of farmers was that the relationship between slope orientation and available solar radiation hindered the use of the minisett technology. Slope orientation was described in terms of 'back ridge' and 'front ridge.' According to these farmers, cultivating minisett yams on certain slopes without the use of yam sticks (one of the main components of the minisett system implemented in Jamaica) would be disastrous. They argue that minisett could not be grown on 'back ridges' because these slopes do not receive adequate sunshine and especially on clay soils, this often result in yams being 'chilled' because soil temperature is too cool [27-29]. This problem would be compounded by the use of plastic mulch. In the traditional yam stick system yams grown on back ridges require much taller sticks than those grown on front ridges. In microclimatological terminology 'front ridge' and 'back ridge' are formally known as adret and ubac slopes. It is an established fact that in the northern hemisphere, the north facing ubac slopes are cooler than the south facing adret slopes as they receive less solar radiation. The farmers' local knowledge is supported by scientific fact in this case. This is a significant hindrance in the minds of farmers. The issue takes on even greater significance when viewed in the context of limited access to land.

The fundamental factor at work is the perception of farmers that the minisett system of yam production has no potential to make them more productive and profitable. It is quite clear that the farmers have not been convinced about the alleged advantages of minisett. Its prospect for wide spread adoption by Jamaican yam farmers is dependent upon the ability of the proponents of minisett to change this perception. This will require not only a change in the dissemination strategy, but the active involvement of farmers in designing a system that suits their needs, is appropriate to farm conditions and incorporates changes to the cultural ecology of yam cultivation that are acceptable to farmers. Very importantly the sharp differences between minisett and the traditional system must be minimized (Table 2).

An important point of discussion is the comparative advantage ascribed to minisett in terms of profitability. This is based on analyses of comparative cost expenditures and income earnings for the minisett system and the traditional system. The latter because of its labor intensive nature is thought to have far higher costs of production, with cost of labor being the single greatest expenditure. This analysis typically overestimates labor costs in the traditional system, as it does not take into 
consideration the fact that a significant amount of labor is procured through informal customary arrangements which do not involve paying for labour.

Table 2. Main differences between the traditional system and minisett.

\begin{tabular}{ll}
\hline Traditional system & Minisett system \\
\hline Uses individual hills & Uses continuous mounds \\
Yam sticks indispensable & Yam sticks not required \\
Uses large planting setts & Uses very small planting setts \\
Uses head setts only & Uses head, middle and tail setts \\
Produces large tubers & Produces very small tubers \\
Setts planted directly in fields & Plants transplanted in fields from nurseries \\
\hline
\end{tabular}

\subsection{Prospects for Minisett Adoption in the Context of Innovation Diffusion and Adoption Theory}

Previous research found that institutional deficiency in the dissemination strategy is a major reason for the negative perceptions most farmers have about the minisett system [27]. The attitude of farmers to minisett yam cultivation remains generally dismissive, but could change if farmers were convinced of the benefits of the system. Changing this attitude will be a long-term endeavor. The task is to convince farmers of the viability of the system. To do this, farmers must be convinced of its advantages over the traditional system. At present farmers think that minisett cannot help them. This is important, for as Wilkinson and Cary argue, unless people are convinced that a change will solve their problems, they will not change their production systems [29]. The question is how can local farmers be persuaded of the utility of the minisett system? One way is to involve farmers in the design of a modified system of minisett, which they believe in and feel is beneficial. The agencies involved in the dissemination of minisett should forge partnerships with farmers and utilize their vast indigenous knowledge of local conditions to create a system that they perceive to be beneficial to them [30,31]. Farmers are the biggest stake holders in this issue and the dissemination strategy should reflect this. Rogers argued that good ideas do not sell themselves [32]. A comprehensive educational campaign which is farmer centered is required. This would include serious consultations with local yam farmers and the establishment of field trials and demonstration plots under normal field conditions based on these consultations. The concept of adaptive on-farm research seems quite appropriate here [33].

Research into the decision-making process of small-scale farmers in Jamaica has indicated that that there are many factors at work in the choices they make about agricultural innovations [27]. It is also clear that the adoption of innovations occurs differentially. Some innovations are adopted quickly, but others take longer [33-35]. Also, farmers do not think in terms of adoption or non-adoption as scientists and academics do, but are more likely to selectively practice innovations based on their constantly changing circumstances [36]. This should be taken into consideration in the dissemination strategy.

Farmers need time and constant feedback to be convinced that the practices they have used for generations can be improved for their benefit [37]. Rogers identified five stages in the adoption process - awareness, interest, evaluation, trial and adoption. In the awareness stage the individual becomes aware of the innovation but lacks complete information to about it. The interest stage is 
where the individual develops interest in the new idea and seeks additional information about it. At the evaluation stage the individual mentally assesses the value /utility of the innovation and decides whether or not to try it. If he decides to try it the trial stage is entered and if he continues to use it then adoption has occurred [33]. This research indicated that with respect to minisett yam around 88 percent of the farmers are still only at the awareness stage with less than 10 percent at the interest stage and just over two percent at the evaluation stage. Given this analysis, the prospects for minsett adoption are not bright.

Farmers also want to be involved in the research process. Seventy nine percent expressed their openness to trying new technologies and ideas. This innovative nature of small-scale food farmers has been noted by other research [16,37-38]. This was so even where there was an element of risk involved. However, the level of risk has to be acceptable or tolerable- measurements determined by socio-economic and personal variables and consequently these vary greatly among farmers. New technologies must make sense to them in terms of bringing advantages and must fit into their smallscale farming system framework. This framework typically has a low tolerance for risks and uncertainty that place the farm family at risk of losing more than the present crop. This is perhaps inevitable given the economic realities under which small-scale farmers operate-realities characterized by low resource base, small holdings, insecure tenure and difficulties obtaining loans just to name a few. Small-scale farming systems are, therefore, often characterized by a risk minimization strategy. This approach has been referred to elsewhere as rational conservatism [27]. The bottom line is that farmers need to be convinced of the benefits of the system to them and its advantages over the status quo.

A critical point to be addressed in any diffusion strategy is the role that opinion leaders can and should play. The phenomenon of leadership has been known for many years to be an important factor in innovation adoption in many different parts of the world [30,39]. In the context of this study opinion leaders were very influential in the attitude of farmers to minisett. Certain distinct characteristics typified farmers who were considered to be leaders of their local communities. First and foremost they operated more successful and potentially successful farms. Secondly, they were generally more educated than their peers. They are more aware of outside sources of information and more likely to consider making new ideas and practices. Age is not a factor in determining leadership status although farmers over age 45 are more likely to be opinion leaders. This may have more to do with the fact that these farmers tend to be more established and more successful than their younger peers than age per se.

The importance of opinion leaders may be illustrated by the example of a farmer in another yam growing area of the parish of Trelawny who had taken the suggestions of the Ministry of Agriculture and made dramatic modifications to successfully grow a species of yam not considered suitable for minisett [8]. More significantly, this young farmer had managed to influence a small group of four other farmers to try his system on their farms. His ability to do this was due to his status as a 'big' farmer and an advisor in the community. More importantly, however, was the demonstration of the success of the system by a respected member of the farming community under normal farm conditions. This is a great lesson with relevance for the overall minisett diffusion strategy. A small farmer in an obscure rural community has been able to achieve all be it on small scale, what the official agencies responsible for disseminating the technology have had very little success doing. 


\section{Conclusions}

There are significant environmental and economic benefits to be gained by seriously promoting the use of minisett by yam farmers. The appeal of minisett is particularly strong from a sustainable agriculture point of view in the context of the nonuse of stakes and the obvious environmental implications of this. On suitable terrain and soils the technology can be modified to fit the needs of local farmers. For example, the farmers could be encouraged to use green manure rather than the more expensive plastic mulch and also to use larger planting setts, which would relieve their concerns about tuber size and yield.

The research indicated that lack of accurate information and a top down and unenthusiastic diffusion strategy are major reasons for the negative attitudes of farmers towards minisett yams. It is quite obvious, therefore, that a well organized concerted dissemination strategy is required to sell the superior benefits of minisett to the farmers in the area. This strategy should involve farmers, integrate modifications based on farmers' perspectives, make use of their farm level experimentations and local knowledge and draw on the largess of opinion leaders.

The dissemination strategy should be persistent and long term given the nature of innovation adoption by farmers in the developing world. Casey, Caviglia-Harris, Kahn and Rivas [40] cite the seminal works of Griliches (1957) and Mansfield (1971), who postulated that the diffusion of a new technology will occur slowly at first before accelerating with the spread of information about it and slowing down again when adoption by farmers approach 100 percent. Innovation adoption in the developing world, however, tends to be slow and rarely reaches the point of rapid diffusion [40].

\section{References}

1. Campbell-ChinSue, H. Advantages and disadvantages of minisett technology; Inter-American Institute for Cooperation in Agriculture: Kingston, Jamaica, 1995.

2. Campbell ChinSue, H. Improved Technology for Yam Production; Inter-American Institute for Cooperation in Agriculture: Kingston, Jamaica, 1992.

3. Barker, D.; Beckford, C.L. Plastic yam and plastic yam sticks- perspectives on indigenous technical knowledge among Jamaican farmers Tifdschr. Econ. Soc. Geogr. 2006, 97, 533-544.

4. Beckford, C.L. Yam cultivation, the yam stick trade and resource depletion in the yam growing regions of central jamaica: Integrated problems for planning and resource management. Ph.D. dissertation; Department of Geography, The University of the West Indies: Trinidad, India, 2000.

5. Barker, D.; Beckford, C.L. Yam production and the yam stick trade in Jamaica: Integrated problems for resource management. In Resources, Planning and Environmental Management in a Changing Caribbean; Barker, D., McGregor, D., Eds.; The University of the West Indies Press: Kingston, Jamaica, 2003; pp. 57-74.

6. Dixon, H.; Bennett, N. Yam stick survey report; Forestry Department and South Trelawny Environmental Agency [STEA]: Trelawny, Jamaica, 2003.

7. Evans, P. Agro-forestry development in the yam growing regions of central Jamaica. Food and Agricultural Organization [FAO]: Rome, Italy, 1994. 
8. Beckford, C.L.; Barker, D. The role and value of local knowledge in Jamaican agriculture: adaptation and change in small-scale farming. Geogr. J. 2007, 173, 118-128.

9. Okoli, O.; Igbokwe, M.C.; Ene, L.S.O.; Nwokoye, J.U. Rapid multiplication of yam by minisett technique; Research Bulletin No. 2; National root Crop Research Institute: Nigeria, 1982.

10. Lawani, S.M.; Umoh, J.S.; Odubanjo, M.O. A bibliography of yams and the Genus Dioscorea; International Institute of Tropical Agriculture: Ibadan, Nigeria, 1983; Vol. 2, pp.1975-1983.

11. Iwueke, C.C.; Mbata, E.N.; Okereke, H.E. Rapid multiplication of seed yam by minisett technique; Research Bulletin No. 9; National Root Crop Research Institute: Nigeria, 1983.

12. Campbell-ChinSue, H.; Fielding, W.J.; Reyes-Pacheco, A. Adoption of minisett technology in Jamaica; Inter-American Institute for Cooperation in Agriculture: Kingston, Jamaica, 1995.

13. Payne, H. A need for change in land-use and husbandry in the Jamaica yam industry; Caribbean Agricultural Research and Development Institute: Kingston, Jamaica, 1976.

14. Mahfood, D.M. Evaluating technologies for yam production: Case study from a Jamaican farm; Inter-American Institute for Cooperation in Agriculture: Kingston, Jamaica, 1993.

15. Strachan, O.M. The agricultural sector performance 1989-1993; Inter-American Institute for Cooperation in Agriculture: Kingston, Jamaica, 1995.

16. Richards, P. Agriculture as a performance. In Farmer First: Farmer innovation and agricultural research; Chambers, R., Pacey, A., Thrupp, L.A., Eds.; Intermediate Technology Publications: London, UK, 1989; pp. 39-45.

17. Thomasson, D.A. Montserrat kitchen gardens: Social functions and development potential. Carib. Geogr.1994, 5, 20-31.

18. Brierley, J.S. Kitchen gardens in the West Indies, with a contemporary study from Grenada. $J$. Trop.Geogr. 1976, 43, 30-40.

19. Brierley J.S. Kitchen gardens in the Caribbean, past and present: Their role in small farm development. Carib. Geogr. 1991, 3, 15-28.

20. Hills, T.L. The Caribbean food forest: Ecological artistry or random chaos? In Small-Farming and peasant resources in the Caribbean; Brierley, J.S., Rubenstein, H., Eds.; University of Manitoba Press: Winnipeg, Canada, 1988; pp. 1-28.

21. Beckford, C.L.; Barker, D.; Bailey, S.W. Adaptation, innovation and domestic food production in Jamaica: Some examples of survival strategies of small-scale farmers. Singapore J. Trop. Geogr. 2007, 28, 273-286.

22. Barker, D. Dualism and disaster on a small tropical island: some constraints on agricultural development in Jamaica. Tifdschr. Econ. Soc. Geogr. 1993, 84, 332-340.

23. Planning Institute of Jamaica. Economic and Social Survey of Jamaica, 2004; Planning Institute of Jamaica: Kingston, Jamaica, 2005.

24. Planning Institute of Jamaica. Economic and Social Survey of Jamaica, 2001; Planning Institute of Jamaica: Kingston, Jamaica, 2002.

25. Protz, M. Growing Minisett Yam in Jamaica: Manual for farmers; Inter-American Institute for Cooperation in Agriculture: Kingston, Jamaica, 1993.

26. Barker, D.; Beckford, C.L. Unearthing the yam stick problem: Insights into farmer innovation in Jamaica. PLECserve-United Nations University and Australian National University; Available online: http://c3unu.edu/plec (accessed January 2007). 
27. Beckford, C.L. Decision-making and innovation among small-scale yam farmers in central Jamaica: A dynamic, pragmatic and adaptive process. Geogr. J. 2002, 168, 248-259.

28. Beckford, C.L.; Barker, D. Finding sustainable ways of staking yams and sourcing yam sticks in Jamaica: An environmental and economic imperative. Carib. Geogr. 2002, 13, 145-155.

29. Wilkinson, R.; Cary, J. Sustainability as an evolutionary process. Int. J. Sustain. Dev. 2002, 5, 381-391.

30. Leeuwis, C.; van den Ban, A.W. Communication for Rural Innovation: Rethinking Agricultural Extension, $3^{\text {rd }}$ Ed.; Blackwell Science Ltd: Oxford, UK, 2004.

31. Scott, J. Social Network Analysis: A handbook; Sage Publications: London, UK, 2000.

32. Rogers, E.M. Diffusion of Innovations, Fourth Edition; The Free Press: New York, USA, 1995.

33. Chin, A.V. On-farm adaptive research in Jamaica: the cropping system project; Inter-American Institute for Cooperation in Agriculture: Kingston, Jamaica, 1993.

34. Buskins, V.; Yamaguchi, K. A new model for information diffusion in heterogeneous social networks. In Sociological methodology; Becker, M., Sobel, M., Eds.; Blackwell: Oxford, UK, 1999; pp. 281-325.

35. Ilbery, B.W. Agricultural Geography: A Social and Economic Analysis; Oxford University Press: New York, USA, 1985.

36. Rhoades, R. The role of farmers in the creation of agricultural technology. In Farmer First: Farmer innovation and agricultural research; Chambers, R., Pacey, A., Thrupp, L.A., Eds.; Intermediate Technology Publications: London, UK, 1989; pp. 3-9.

37. Williamson, V.; Reyes-Pacheco, A. Will small yam farmers in Jamaica adopt the minisett technology? Inter-American Institute for Cooperation in Agriculture: Kingston, Jamaica, 1996.

38. Pretty, J.; Guijt, I.; Schoones, I.; Thompson, J. Regenerating Agriculture: The agroecology of low-external input and community development. In Sustainable Development; Kirkby, J., O’Keefe, P., Timberlake, L., Eds.; Earthscan Publications Ltd: London, UK, 1999; pp. 125-145.

39. Zawisza, S.; Pilarski, S. Opinion leadership and information sources in agricultural innovation diffusion processes (on the basis of selected villages in the Kujawsko-Pomorskie province in Poland). Electron. J. Polish Agric. Univ. 2005, 8. Available online: www.epau.media.pl/volume8/ issue4/art-28.html (accessed August 8, 2006).

40. Casey, J.F.; Caviglia-Harris, J.L.; Kahn, J.R.; Rivas, A. Information and the subsistence farmer's decision to deforest in Latin America. Int. J. Sustain. Dev. 2002, 5, 392-414.

(C) 2009 by the authors; licensee Molecular Diversity Preservation International, Basel, Switzerland. This article is an open-access article distributed under the terms and conditions of the Creative Commons Attribution license (http://creativecommons.org/licenses/by/3.0/). 